\title{
“Get a Life!" Anti-Television Agitation and Activism
}

\begin{abstract}
No modern medium has been detested as much as television. The chapter reviews key works by Mary Whitehouse, Marie Winn, Jerry Mander and Neil Postman deeming television to be a cause of social ills in the 1960s, 1970s and 1980s. Television was seen to undermine democracy, community and enlightenment, obstructing a moral lifestyle, and impairing mental and physical health. The chapter discusses collective action against television through movements such as TV-Free America, the British White dot and Adbusters. While anti-television activism did not inspire a general rejection of television, TV-Turnoff Week from the mid1990s became a way for organizations, professions, communities and individuals to demonstrate their resentment and point to television as an explanation for social change to the worse.
\end{abstract}

Keywords Television . Tv-turnoff - Tv-boycott · Idiot box · Passive viewing

\section{The Chief Culprit}

Max Horkheimer and Theodor W. Adorno had not had much chance to watch television when they published The culture industry: Enlightenment as mass deception, in 1944, but they had heard about it. Describing it as "a synthesis of

*is used throughout the book to indicate my translation.

(C) The Author(s) 2017

T. Syvertsen, Media Resistance,

DOI 10.1007/978-3-319-46499-2_4 
radio and film," they expected its effect to be "enormous" and that it would drastically "intensify the impoverishment of aesthetic matter" $(1997,124)$. Horkheimer and Adorno echoed sentiments expressed in other texts from the same period, including views attributed to characters in dystopic fiction such as Brave New World, Nineteen Eighty-Four and Fabrenheit 45I (Ch. 3).

Narratives of warning are an important part of media history and inform us about expectations at a time when few have first-hand experience with a new medium. Yet, television scepticism did not disappear once the medium matured. Instead, narratives of warning gave way to narratives of explanation, pointing to television as a cause of social change to the worse. In the post-war decades of massive social transformation, television became "the chief culprit in the alleged decline and fall of contemporary culture" (Brantlinger 1983, 19).

This chapter is about writers and activists who did not become convinced that television was a good thing. Since television continued to grow in importance, resistance can be studied as a lost cause; resisters are just moralists, luddites and pessimists who never seem to catch up. To antitelevision writers or activists, however, it is the television crowd who does not get it. As argued in a campaign for TV-turnoff week (2012), turnoff is not about saying "no" but saying "yes":

National TV-turnoff Week is about having more fun and turning "on" your life. It's an opportunity to rediscover the wide range of activities that exist when one unplugs from the sedentary, image-based, simplistic and commercial world of television.

This chapter provides insight into television resistance through a discussion of selected writers and cases. The first part of the chapter discusses resistance literature; specifically four writers who were widely read at the time and illustrate a broad range of concerns about television. Mary Whitehouse was a British schoolteacher who organized a major television-critical movement from the 1960s in the UK, whereas Jerry Mander, Neil Postman and Marie Winn separately and together inspired television resistance in the US and internationally in the 1970s and 1980s. The chapter explores how central values in media resistance, for morality and culture, enlightenment and democracy, community and health (Chs. 1 and 2), emerge in televisioncritical arguments and actions, and points to the rise of new metaphors, such as "couch potato" and "the idiot box," implying that viewers were lazy and the content harmful and stupid. 
In the second part of the chapter, I discuss resistance movements; organized action to reduce the importance of television. Based on websites, media interviews, statements and documents, the ideologies and methods adopted by TV-Free America, Adbusters, White dot and TV-turnoff week are discussed from the mid-1990s until the early 2000s. The emphasis in this chapter is not on reception of new media, but rather on resistance to an established medium; providing an alternative to the usual narrative where scepticism and fear give way to acceptance.

Historical and social conditions shaped television resistance and television evolved differently in different contexts (see, for example, Smith and Paterson 1998). In particular, there are differences between the US, adopting a commercial model for broadcasting, and the European public service tradition (see also Ch. 2 on radio). In this chapter I draw predominantly on examples and cases from the US and UK, with some examples from Scandinavia and elsewhere. With public service television and a lower level of consumption in Europe there is less of a history of anti-television action once the medium matured; anti-television activism had more support in the US, where the commercial system gave protesters more to despise. However, both agitators and forms of activism travel across borders and operate in different national contexts.

Although it is not easy to draw a firm line, two positions emerge in the material discussed. On the one hand, there are those who reacted to television's content, genres and functions, but believed that the medium could be improved. On the other hand, there are those who saw television as irredeemable, and advocated its elimination.

\section{Cleaning Up Television}

British schoolteacher Mary Whitehouse began her campaign to "clean up" television in 1964. Whitehouse, who would become one of the twentieth century's most avid media protesters, initially held high hopes for television. But soon anger and disappointment set in; this was Britain in the sixties and a more permissive climate had begun to influence the public broadcasting ethos.

As one of the early examples that awakened her, Whitehouse refers to a discussion on pre-marital sex on the BBC in March 1964. Several speakers indicated that premarital sex was not immoral if certain conditions were met. This had a direct impact on the girls in her class, who, according to 
Whitehouse, instantly learned that it was acceptable to have intercourse when engaged to be married:

This made a tremendous impression on me.... Had a few adults... been able to swing the thinking of a generation and manage to destroy in a few minutes their traditional concepts of right and wrong? $(1967,16)$

During the summer of 1963, Whitehouse contacted broadcasters as well as the Minister of Health and leading members of the church. She was courteously received by all, and returned to the school feeling "that things would surely improve" $(1967,19)$. What happened instead was that the BBC launched a series of plays that autumn which, as Whitehouse saw it, reached "a level of depravity not seen before or - with some notable exceptions since" $(1967,19)$. Disillusioned and angry, Whitehouse drafted a manifesto which became the basis for a mass mobilization: "Women's organisations, magistrates, church leaders, feature writers, public figures and private people all joined in" $(1967,19)$. The campaign is detailed in her 1967 book, Cleaning up TV. From protest to participation and in the autobiography Quite Contrary (1993, see also Tracey and Morrison 1979).

For Whitehouse, a devout Christian, what was at stake was morality, that is, fundamental questions of right and wrong. Moral campaigns against television had much in common with earlier protests against popular fiction, cinema and comics (Ch. 2), and later protests against videos, games and online pornography (Chs. 5 and 6). Moral campaigners of various inclinations do not necessarily dislike the media, but campaign to get them back on track - back to the role of offering moral guidance. The manifesto of Clean-up TV begins: "We women of Britain believe in a Christian way of life," and goes on to demand that the BBC should produce programmes "which build character instead of destroying it, which encourage and sustain faith in God and bring Him back to the hearth of our family and national life" (Whitehouse 1967, 23).

What distinguished Whitehouse from other TV-critical campaigners was her organizational talents and exceedingly high number of supporters. The campaign with 7000 activists was run from a bedroom in her house $(1967,42)$. The manifesto was distributed in steelworks, factories, schools and hospitals, it was read aloud in churches all over Britain, and gained nearly half a million signatures. Whitehouse received more than 35,000 letters of concern, enjoyed strong support from the police and was invited to meet Pope Paul VI $(1993,37)$. Whitehouse travelled all 
over Europe, the US and Australia, inspiring supporters and establishing local chapters. The campaign turned into the Viewer's and Listeners' Association in 1965, which went on to protest against other media and genres (Whitehouse 1993, Tracey and Morrison 1979). Among their victories they counted a law against "video nasties" in 1984 (Barker 1984b, ch. 6) and the establishment of a Broadcasting Standards Commission from 1996.

Despite the strong reactions to television, Whitehouse did not encourage abstention. On the contrary, close monitoring by hundreds of volunteers provided the programme samples that were brought to politicians, broadcasters and courts as ground for protest. Whitehouse represents a type of television resistance that primarily reacted to offensive content and put pressure on authorities to impose restrictions; but as her campaign expanded, so did also the liberalizing forces. "As I write I can already hear the snorts of indignation from the 'freedom for television' advocates," Whitehouse commented on the growing anti-censorship lobby (1967, 17). Whitehouse was met with formidable opposition and a range of negative labels were attributed to her; but in contrast to many later activists, who struggled to show that they were not simple-minded moralists, Whitehouse took a more confrontational stance. "It is sometimes suggested that we are 'non-intellectual' and 'unimaginative'," she wrote, and continued, "Well, what if we are? Have we any less right to make our views known?” $(1967,29)$.

\section{Mander and the Elimination of Television}

On the other side of the Atlantic, Jerry Mander had started out a successful advertising executive, but after a while, he reports that he "began to realize a kind of hollowness in myself" (Mander 1978, 15). The 1960s provided opportunities for getting involved in social and political protests, and with his skills in advertising, Mander aided activists wanting to use television for beneficial purposes. However, for Mander himself, this only led to disappointment. Slowly he came to realize that television was irredeemable, in his words, it could not be used to spread "prosocial values" (36-39). In Four arguments for the elimination of television (1978, first publ. 1977), an almost 400 page long manifesto littered with references to social decay - Brave New World, Nineteen Eighty-Four and Fahrenheit 451 are all points of reference - Mander 
argues that television will destroy democracy and lead to authoritarian rule.

The historical context for Mander's criticism was US television at the height of the network era. Whereas television everywhere drew criticism of triviality, the US system alienated more with its blatant commercialism and "lowest common denominator" programing (Giersing 1986). Already in 1961, the Head of the US Federal Communication Commission proclaimed US television "a vast wasteland" for its endless procession of game shows, westerns, formula comedies, violence, murder and sadism (Minow 1961). Mander's vocabulary resembles Marxism in some parts, he argues that television drives us into a capitalist consumer culture and creates false needs (126). Television is an agent of indoctrination and brainwashing: "We accept whatever comes. ...We have lost control of our minds" (112). However, the analysis is not limited to political or economic concerns; he believes the technology itself to be at fault (261):

Television's highest potential is advertising. This cannot be changed. The bias is inherent in the technology.

According to Mander, television's built-in demand for polarization and dramatization implied that it was unable to convey subtlety; too many crucial pieces "fall through the filter" (323). Mander lists what he sees as 33 inherent biases in the television technology, including "l. Violence is better TV than nonviolence," "9. Superficiality is easier than depth," "13. Lust is better television than satisfaction," "14. Competition is inherently more televisual than cooperation" and " 21 . The bizarre always gets more attention on television than the usual" (323-328).

In media studies, the view that the medium's technology is more important than content, is often labelled "medium theory" (Meyrowitz 1985, 16; Croteau and Hoynes 2012, 299). First among the medium theorists is Marshall McLuhan (1968) known for the dictum "the medium is the message" and theories of how new media reshaped social life. Although McLuhan was a media and technology enthusiast, similar ideas were discussed at the time with a dystopian slant. For example, the German philosopher Günther Anders in 1956 formulated ten theses about how the broadcasting technology would enslave humanity: " $[\mathrm{B}] \mathrm{y}$ virtue of their fixed structure and functions" the broadcasting media 
created a pseudo-reality, he argued, where we would live our lives as "minors and subordinates" (Anders 1956).

In academic accounts, this type of thinking is routinely classified as technological determinism; overstating technology and understating agency (Croteau and Hoynes 2012, 290). Yet, social and political manifestos like Anders' and Mander's are not academic studies, and their most interesting characteristic is not where they can be placed on a simple dichotomy. Instead, it is interesting how they eclectically draw on a variety of concerns and observations in order to explain why media are bad. In addition to his overarching concern that democracy is under threat, Mander sees television to destroy mental and physical health, based on stories about viewers who have turned "sick, crazy, mesmerized" (157), he discusses television inability to convey art and culture (272-273) and laments the loss of community: "The extended family is gone and neighbourhood community gatherings are increasingly the exception to the rule" (254). Mander himself was no fan of McLuhan; he felt that McLuhan's thinking "did not help us very much," calling his terminology "talk show patter" and "wordplay" which "became the basis of hundreds of conferences and thousands of cocktail party debates" (30).

\section{Huxley was Right: Postman and Amusing \\ Ourselves to Death}

Neil Postman, educator and self-professed "media ecologist," sold more than 200,000 copies of his 1985 anti-television manifesto, Amusing Ourselves to Death (2005a, figures according to Wikipedia). The book began as a lecture at the 1984 Frankfurt Book Fair commemorating Orwell's dystopian vision, but Postman argued that Orwell did not get it right after all. Television did not lead to authoritarian rule; instead, television was realizing the Huxleyan warning of turning public life into entertainment (3-4). "Television does not ban books, it simply displaces them" (141), says Postman in a catching phrase, although a phrase which stretches Huxley's narrative. In Brave New World books are not merely "displaced," as we have seen (ch. 3); instead Huxley depicts a society where literary culture is forcefully repressed, there is widespread censorship, and babies are conditioned with electrical shocks to resist books. 
Postman pays tribute to McLuhan for pointing out that function is more important than content (8), but is no fan of Mander, calling his book in passing for a "straight Luddite position" (158). Postman is not alarmed by the threat of authoritarianism - what he sees as the Orwellian dystopia - but television's ability to turn everything into entertainment. What is at risk for Postman is the entire enlightenment project; television undermines reason, rationality and print culture, the very foundations of society. "Most of our modern ideas about the uses of the intellect were formed by the printed word, as were our ideas about education, knowledge, truth and information" (29), he writes. But in the 1980s The Age of Television had completely succeeded The Age of Typography. Under the governance of the printing press, public discourse was "coherent, serious and rational," but under the governance of television it had become "shrivelled and absurd" (16), "getting sillier by the minute" (24).

Postman's message is classical pro-print, anti-screen. And while Mander had tried to use television for beneficial purposes, Postman sees no purpose in trying. But the conclusions are the same: television is irredeemable. Postman speaks specifically against news, current affairs, educational television and public broadcasting programmes such as 60 Minutes and Sesame Street; instead of trying to fill television with good content his view is: The worse the better! He asserts that television (159)

serves us most usefully when presenting junk-entertainment; it serves us most ill when it co-opts serious modes of discourse - news, politics, science, education, commercial, religion - and turns them into entertainment packages. We would all be better off if television got worse, not better.

Postman's book was extremely successful; it was translated into a dozen languages, including German, Indonesian, Chinese and Scandinavian languages (Postman 2005b, viii). Postman himself travelled the world at a time - the mid-1980s - when the broadcasting monopolies were toppling and commercialization and globalization hotly debated. In these debates, there was demand for voices to condemn commercial broadcasting and defend public service, and it testifies to Postman's flexibility that he adjusted his arguments to fill the role. On a visit to Norway in 1987, he warns against the introduction of advertising on television, this would "be equal to meeting a slow death as unenlightened people"* (Aftret and Jacobsen 1987). Apparently, the idea that 
television ought to get worse not better, and that commercial television and junk-entertainment was better than public and educational television, did not apply overseas.

\section{Winn and the Plug-IN-Drug}

Marie Winn, a translator, author, birdwatcher and an advocate for protecting wildlife, based her bestselling manifesto The Plug-In Drug (1980, first publ. 1977) on a huge amount of testimonials. Winn herself had been inspired to engage with television after observing her children watching Flintstone and I Love Lucy, noting that "the children's chins and jaws were hanging limply, their eyes glazed over and expressions vacant"* (Shulins 1987). Although she later claims that her purpose was not "to promote its elimination altogether" (Winn 2002, $\mathrm{x}$ ), her argument is that television is not a symptom of social ills, but the actual cause:

There are two ways to consider television in our society. Its use and overuse may be seen as symptoms of other modern ills: alienation, dehumanization, apathy, moral vacuum. Or one can regard the television set at as a pathogen, a source of such symptoms $(1980,245)$.

Like Mander and Postman, Winn is critical of attempts to improve television or using it for beneficial purposes (6). She ridicules researchers for measuring the effects of specific content, when what matters is " $\mathrm{t}]$ he very nature of the television experience" (3). Although Winn sees television itself to be the problem, her concerns differ from Mander's and Postman's, and she calls McLuhan "apocalyptic" (3).

To Winn, television destroys mental and physical health, and undermines community, particularly its key element: the family. Life with television is life without stimulation, with television we see a reversal of human development, she draws parallels with animals raised in cages and children raised by animals. Television is addictive, like drugs and alcohol, and impairs cognition, visualization and concentration. To Winn, the changes of lifestyle in the 1960s and 1970s are only negative, and probably all due to television:

There is no proof that television viewing is seriously related to declining verbal abilities, to the appearance of a new life style, to alarming trends such as drug use and drug abuse among increasing numbers of young people. But 
when all the elements of the puzzle are brought together and examined, television seems seriously implicated in the outcome of the first generation that grew up under its influence. And something is odd about the new generation, something is wrong somehow... (115-116).

Winn is also eclectic in her concerns; in addition to concerns for community and mental health she points to loss of moral guidance and enlightenment; television impairs reading and particularly the crucial ability of "inner picture-making" (1980, 64). However, what distinguished Winn from other critics is her practical approach; she proposes concrete methods to tackle the problem.

\section{A Call to Action?}

Those who believed that television could be improved, like Whitehouse, could rely on a trusted arsenal of campaigning methods. Those who believed it to be irredeemable faced bigger challenges. Mander, Postman and Winn were no fans of teaching media literacy, which was favoured by many scholars and critics as a response to increased media use and content perceived to be problematic (see, for example, McGrane and Gunderson 2010). Yet, they were battling with what to propose instead.

Since television subverts democracy, the democratic process should ideally be used to subvert it, Mander writes $(1978,353)$. But he is not optimistic. Since television colonizes the mind, people would not vote for anyone suggesting abolition. In a postscript called "Impossible thoughts," he recounts the reactions when he tells people that television should be abolished:

"I couldn't agree with you more", would be the invariable response, "but you don't really expect to succeed, do you?" (347)

In an introduction to the 25th anniversary edition, Postman's son, Andrew, calls his father's book "a call to action" (2005b, xiii). However, the original text does not really make it clear what action Postman recommends. $\mathrm{He}$ discusses and rejects several methods and describes "insurmountable difficulties" in suggesting "remedies for the affliction" (2005a, 158). Postman asserts that "[ $\mathrm{m}]$ any civilized nations limit by law the amount of hours television may operate and thereby mitigate the role television plays in public 
life," yet mentions no country or legal measure (158). He toys with the idea that satire may demonstrate how ridiculous television is, but notes sadly that performers would become celebrities and "television would have the last laugh" (162). His best hope is in education, but he laments that teachers are not teaching children to "distance themselves" (163). So this solution is also "desperate" and "naive" in Postman's own words (162).

Winn battles less with the question of what to do. Part IV of her book titles "No television" and contains reports and testimonies from people who have given up television, including a report from an experiment she initiated in Denver in 1974 where families were encouraged to turn off television for a month $(1980,220-229)$. This was presumably the first organized TV-boycott in the US (Winn 1987, xiv), but others were soon to follow (Fang 2015, 7; Winn 1987, 131-133). The event that gained the most publicity, both in the US and overseas, was a month long turnoff initiated by the Library Council of Farmington in 1984, where more than a thousand residents took part (Winn 1987, 132). Librarian Nancy de Salvo, the chief organizer, appeared by phone on The Letterman Show, where she was offered a bribe to turn her television back on, but did not give in (Freedman 1998). The event is discussed by Postman (2005a, 158-159) and cited as an explicit source of inspiration for TV-Free America (Hirsch 1998).

Inspired by these events, Winn publishes a second book in 1987 - an action manual called Unplugging the Plug-In drug: The "No TV Week" Guide. The book advocates consumer boycotts of television, in the same way as activists initiated boycotts in other businesses and markets (Friedman 1999). The book contains everything needed to organize a television boycott: sample invites to meetings, press releases, pledges to sign for participants, notes to speakers etc. In addition to practical advice, the book demonstrates awareness of potentially negative reactions and warns against moralizing. For example, "How to Organize and Run a Parent's Meeting About Television" starts with a warning that "the tone of your presentation is crucial; a 'We're all in this together' attitude is more persuasive than a 'I am here to make you see the light' approach" $(1987,179)$.

\section{TV-Free America}

In the 1990s, activists on both sides of the Atlantic responded to the call. Inspired by literature and boycotts, as well as their own negative experiences, the time had come for collective action to rid the world of 
television. TV-Free America, founded in 1994, was the first to institutionalize annual $T V$-turnoff weeks, followed by networks such as Canadianbased Adbusters and British White dot. As stated on the website in 2002, the network was

dedicated to the belief that we all have the power to determine the role that television plays in our lives. Rather than waiting for others to make "better" $\mathrm{TV}$, we can turn it off and reclaim time for our families, our friends and for ourselves (TV-Turnoff 2002a).

The two founders of TV-Free America, Henry Labalme and Matt Pawa, are described in interviews as environmentalists and intellectuals, a political scientist and lawyer respectively. Both loved TV at a young age, but turned against it at university. "Once you've taken an extended break" from television, Labalme says in a later interview: "you realize this is so much better. I'm accomplishing so much more.... You wonder, 'How did I ever have time?' to watch so much television" (Hirsch 1998).

The idea to set up a nation-wide network came when Labalme and Pawa were housemates in Georgetown, Washington, in their twenties. Their long conversations "about the decline of literacy, the rise in consumerism and the degradation of the environment kept coming back to television" as a root source of many environmental, social and political problems (cited from Johnson 1996).

The two organizers took time out of their jobs to start TV-free America and initiate the first National TV-turnoff week in 1995 (Johnson 1996). The group immediately attracted publicity. As TV-resisters, Pawa and Labalme refused to appear on talk shows and declined invitations to CNN (Dundjerski 1997). But they willingly appeared in newspapers and embraced the embryonic Internet - filling their website with arguments, statistics, alternative activities and joyful testimonies from the TV-free. They also credited inspirational figures: On the advisory board were Mander, Winn and Postman, as well as DeSalvo, the librarian who had organized the turnoff in Farmington (TV Turnoff 2000a).

Although the founders were eager that the organization should not appear self-righteous, they did not wish to compromise. To TV-Free 
America, short-term turnoffs was a means of getting rid of television altogether. When the first national turnoff was organized in 1995, a primary goal was announced of cutting viewing time in half in ten years (Hirsch 1998). They also take an explicit stand against movements trying to improve content or promoting media literacy as a sufficient solution. In a 1998 interview, Labalme states that "people have been arguing for years about 'good' television vs. 'bad' television - and accomplished very little." Arguing for better television "is like trying to cure alcoholism by switching to better whiskey," he says, attributing the quote to Marie Winn (Hirsch 1998).

$T V$-Free America also takes charge with people who think that some television, such as documentaries or public broadcasting, is somehow acceptable: One question in a QA-page is: "Is all TV bad? What about the Discovery Channel or PBS?" TV-Free America answers:

All TV is passive, sedentary and non-experiential. Most viewers tend to watch show after show - not individual programs. Instead of watching a documentary about birds, go out (with binoculars if you have them) and see how many real birds you can identify in your neighborhood (TV Turnoff 2002c).

Television is rejected because of its flow character (see Williams 2008), but all forms of television and all forms of watching are bad. In a 1998 interview a spokesperson said that "no matter what people do instead of watching the tube - whether they write a letter to the president, wash the dog or do a rain dance - they will be better off" (Dundjerski 1997). Yet, the network wants the message to be positive and not allude to cultural pessimism or moralism. "The idea's not to beat people over the head with this idea that TV is bad for them, that it's rotting their brain, that it's destroying their communities," Labalme says in a 1997 interview: "But to say, try life with a little less TV and a little more time, and you'll have more fun" (Dundjerski 1997). The network actively confronts the image of resisters as sour and fearful Luddites on the outskirts of society. Rather, it is the television viewer who is isolated:

People say TV unites us, especially big events such as the Superbowl... But that is a myth. If you want diversity, walk around your block and if you want community, talk to your neighbors. TV is an isolating medium (Labalme in Freedman 1998). 
Later TV-Free America would put a quote on the website from Ray Bradbury commenting in 2007 on why he wrote Fabrenheit 451 (see also Ch. 3). Rejecting interpretations that the story was a political protest in the McCarthy era, Bradbury stated "I wasn't worried about censorship. I was worried about people being turned into morons by TV" (Kaufman 2007; Rothman 2007). The quote suits the mood of TV-free America well - they do not fear Orwell's Big Brother, they just do not want people to be "morons." The quote also testifies to smugness among abstainers and the belief that non-viewers are smarter. Winn notes how non-viewers felt "evangelistic" $(1980,243)$ and that "a feeling of pride that sometimes borders on the self-satisfied" prevailed among no-television families (240, see also Krcmar 2009).

\section{Grass-Root Activism and Professional Support}

TV-free America claimed to be "a grassroot project that works" (TV Turnoff 2002a). Their main activity, organizing TV-turnoff week, was done in collaboration with local organizers, schools, clubs, community organizations, religious congregations, shops and businesses. According to TV-Free America, there were 5000 local organizers in 1995 (Singer 1996), growing to 35,000 in 1998 (Freedman 1998). Many bought "turn-off kits" at $\$ 10$ apiece with tips for what to do, posters and bumper stickers, readymade leaflets and other campaign material (TV Turnoff 2002b).

Teachers and their allies: professors, librarians and organizations promoting literacy, were among the more ardent supporters. According to organizers, turnoffs were organized in 50,000 schools in 2000 (TV Turnoff 2000c). Press clippings and websites contain numerous examples of activities. Such is a typical report, this one from the second turnoff week in 1996 (Johnson 1996):

In the Inland Northwest, schools promoted the idea with newsletters and posters. Spokane's Jefferson Elementary had a daily prize drawing for students who brought in coupons listing what they did instead of watching TV. Few schools did as much as Windsor Elementary, where parent volunteer Barb Brock, a recreation management professor at EWU, planned activities. She organized a teddy-bear story night, poster contest and distributed information to classes. Nine-year-old Nick Gaddy's family turned off two TVs and borrowed an old record player from the school. "We listened to records," he said. "The big, black ones." 
There is plenty of nostalgia, plenty of community and plenty of fun. Turnoff-reports are littered with ice-cream festivals, parties, picnics and rewards (Johnson 1996). School officials go to great length to please nonwatching pupils and families: One principal spent an entire day on the roof to reward participants (Dundjerski 1997), another let students cut and spike his hair as a reward for staying off television (Kelly 1996). Similar reports emerge from religious congregations and local communities. One typical local report features the 1999 turnoff at the Mandarin United Methodist Church where sixty families were handed red ribbons to tape across their TV-sets, and the event was celebrated with a church picnic (McAlister 1999).

Not all were in it for the fun, however. Paralleling local activism was massive endorsement of TV-turnoff week from state and nation-wide organizations. A 2002 list on the website named seventy endorsers, of which most were national professional bodies (2002e). All major US educational and medical organizations endorsed the campaign, so did also religious bodies, state and local councils, community organizations, and organizations for arts, the environment, sports and the outdoors.

In January 1995, TV-Free America approached the US Catholic Conference of Bishops resulting in a major victory (Johnson 1996). In his March 10th address in St. Peter's Square, Pope John Paul II called upon Catholics all over the world to engage in a TV-fast during Lent (Christus rex 1996):

In many families the television seems to substitute, rather than facilitate, dialogue among people...A type of "fast" also in this area could be healthy.

Public authorities used TV-turnoff week to aid their case. Over the years, the event gained support from a majority of US governors (Freedman 1998; Dundjerski 1997). In 1999, the week was boosted by the support of the US Surgeon General David Satcher; noting that "obesity levels are at epidemic proportions for both children and adults," he wanted to "challenge Americans to break free of TV." Satcher visited an elementary school where he distributed a "Surgeon General's prescription for Less TV," encouraging students to tape them to screens at home. He was accompanied by the Under-Secretary of Agriculture for Food, Nutrition and Consumer Services, Shirley Watkins, who encouraged Americans to "get up off the couch" and "shelve the remote." Echoing the goals of TV-Free 
America, she suggested beginning with a cut of fifty per cent in viewing time (TV Turnoff 2000b).

The organizers themselves pointed to the wide appeal across political, religious and other divides: "We've got the political left and the political right," Labalme said in a 1996 interview, emphasizing the fluid and flexible ideology:

We say turn off the TV for your own reasons: because there's too much sex and violence, because it leads to couch potato-ness, which is a health issue, or because people aren't going to church and losing touch with spirituality (cited from Johnson 1996).

One advantage of the TV-free cause was its adaptability: not only did it appear to serve different values; different organizations could also fit it into their calendar of events and tailor it to their own particular cause or action plan.

\section{Turnoff Travels}

Turnoff spread - to Canada, Australia and New Zealand, Latin America, and to Britain, Scandinavia and elsewhere. In 2002 TV-Free America claimed to have sister organizations in more than twenty countries (TV-turnoff $2002 \mathrm{~d}$ ).

The Vancouver-based network of "culture-jammers," Adbusters, supported the cause from the beginning. While many activists shunned appearing on television, Adbusters produced anti-television commercials. The first was broadcast on $\mathrm{CNN}$ - the only network that would take it - on 22 April 1999 (Adbusters 2002). The commercials are brief television horror stories. For example, the 2007 commercial shows a young man's head trapped inside a set (Adbusters 2007).

In 2001 turnoff is introduced to Sweden and in 2002 to Norway. Television turnoff week did not make deep inroads into the Nordic countries with their tradition of public service broadcasting and their viewing figures the lowest in Europe (Syvertsen et al. 2014). In Scandinavia, boycotting television for a week, instead served to demonstrate the fluidity of the cause and how a television protest could serve different purposes. For example, to the Norwegian Christian media watch organization, Familie og Medier, turnoff was about consumerism, bad role models and contemplation over "how much space the media take in our lives"* (Ulveseth 2005). To the teachers and students at the school of 
Moe in Southern Norway, turnoff was about reading and switching television for books (Stulen 2005). To the municipality of Melhus in midNorway, television turnoff week in 2006 was all about culture. A weeklong arts festival with local performers provided the council an opportunity to launch its new online arts portal, their motto being "to turn off television and get out" to watch local performers* (Refsnes 2006).

In Britain, there were more militant activists. White dot, named after the small dot that would appear when turning off older TV sets, organized TVturnoff from 1996. The primary activist, US-born David Burke, initiated his crusade by climbing on top of a symbolically busted TV set outside Westminster Abbey in 1996 with a sign reading "Get a Life!" He called on Prince Charles to ban TV cameras from his future coronation - whenever that would be. "As the Queen's coronation in 1953 had marked the start of widespread television viewing in the UK, a TV-free Charles coronation would, felt Burke, have a pleasing symmetry to it" (White dot 2009).

White dot did not believe that television could be improved, but were "against the activity of viewing" (White dot 2000a). The network ran small-scale community events, so-called Zocalos, the Mexican word for town square. Neighbourhoods were leafleted to persuade residents to sit outside their houses for a night instead of watching television (White dot 2000b). White dot produced a 300-page resistance manual Get A Life! (Burke and Lotus 1998), promoted child-rearing methods from the preTV age, and marketed anti-television merchandise, such as TV-B-Gone, a device used to turn off TV-sets in cafes and pubs. Its fundamentalist stance is perhaps most visible in an advert for jewellery made by televisions smashed by the Taliban in Afghanistan, where admiration is expressed for the swift and brutal action:

You've got to have a sneaking respect for the Taliban. No messing about with posters or TV-B-Gone's for them. They just came into power, outlawed television and rumour has it they publicly executed one just to drive home the point (Adams n.a.).

White dot also speaks out against teaching media literacy and media studies; which "reinforces in students the idea that the spectacle of television should be the centre of their lives":

It is not in the interest of any media studies professor or textbook author to arrive at the relatively simple truth that maybe television is just not worth the 
time. If the "off" button is the answer, then no media studies course will ever help students find it. By ignoring the "off" button, all media studies can only chase its tail (White dot 2000a).

In 2000s, white dot activists authored Spy TV (Burke and Lotus 2000), a comprehensive analysis of how digital television collects and sells surveillance data. Spy TV suggests that you "visit a department store that sells digital televisions and say you want one that does not offer interactivity, because you have heard they are designed to monitor and manipulate viewers" (141). The authors further invite you to become "Early Rejector" (141), a pun on the concept of "early adopter" from diffusion theory (Rogers 1995). In April 2012, White dot tried to use analogue switch-off to get rid of television for good: "When your set goes fuzzy on Wednesday the 4th, don't fiddle with the remote. Throw it away. Mail it to a friend in another country. Get out of the box!" (Burke 2012).

\section{Television Goes Fuzzy}

Television turnoff-week reported impressive participation: One million in 1995 (Baker 1996), rising to 7.6 million on the tenth anniversary in 2004 (Cai 2014). Compiling the numbers, it was claimed in 2002 that more than 24 million had participated altogether (TV Turnoff 2002a), rising to over 100 million in 2013 and over 300 million in 2016 (the two last figures are from Wikipedia's and include screen-free week, see Ch. 5 and below). The numbers were based on loose report-backs and sales of turnoff kits, and are in no sense verified. It was also evident that despite all this activism, television was still there. Los Angeles Times even comments on how during the 1996 turnoff, television ratings increased (Dundjerski 1997).

This was not a movement prone to hopelessness, however. "I think any major social movement starts that way," says Labalme in a 1998 interview, staking his hopes on declining standards and increased dissatisfaction: "I hear this more and more from people,...'I used to watch a lot, but now it's so bad'." Echoing Postman he asserts "As far as we're concerned, the worse the content gets, the greater the likelihood that people will turn away entirely" (Hirsch 1998).

TV-turnoffs continued in the new millennium, but there is change in the air. In 2010, TV-turnoff week was changed to Screen-Free Week, and, 
allegedly "at Henry and Matt's request," the site was relocated to the lobby group Campaign for a Commercial-Free Childhood (Screen-free week 2014), a group that does not appear to share the staunch anti-TVbeliefs of TV-Free America.

White dot, for its part, continues to update its website with small victories and disappointments. In 2015 they are satisfied that the Catholic Church had got its first TV-free Pope in almost a century, citing Pope Francis as saying that "he promised the Virgin Mary in 1990 that he would never watch again." When the professed non-watcher Ed Miliband became leader of the British Labour Party, the website is hopeful that Britain would get its first TV-free prime minster. As the Conservatives won the 2015 election, the site notes disappointedly "Britain ignores white dot endorsement!" (White dot 2015).

\section{What is at Stake and What to Do?}

The traditional positions elaborated in media resistance: that media do not inspire a virtuous life and do not ascribe to the highest cultural standards, inspired plenty of criticism against television. Whitehouse and her campaign is only one of many examples of moral mobilization against what many saw to be a medium spearheading a liberal revolution. The commercial nature of (particularly) US television, the proliferation of violent entertainment, the head-to-head competition between networks driving out material not intended to entertain, provided plenty of fodder for those who saw television as a cause of moral and cultural decline. The values at stake were similar to those that had motivated reactions to novels, serial literature, cinema and comics, but the position of these concerns in society had changed in the television network era. The liberalization of the cultural climate from the 1960s allowed for a wider interpretation of right and wrong in terms of moral behaviour, and a new understanding of cultural value, where also works of popular culture were admired for their quality. As Menand (2011, xxi) puts it, out went the notion that "the fate of the republic is somehow at stake" in the matter of "what kind of art people enjoy or admire."

Other concerns intensified with television, particularly the concern for educational standards, enlightenment and learning. The concern for passive rather than active uses of the mind was a recurring theme; the flow character and the way audiences were seen to become "couch potatoes" 
were deemed to impair concentration and focus. Passivity was seen as leading to both mental and physical health problems; television viewing was likened to drug use and escalating obesity. Resistance to television was also inspired by its presumed negative effect on involvement in small and large communities - from families to neighbourhoods to municipalities and nations - predating the concerns later spelled out by Robert Putnham in the well-known Bowling alone (2000). Television was not social glue, protesters claimed, but a force of fragmentation, leading to a decline in civil engagement.

Resistance to television was motivated by a concern for democracy and political processes. Mander predicted that television would lead to authoritarian rule, while Postman lamented that politics turned into entertainment. Both referred to Orwell and Huxley's dystopic accounts, while TV-turnoff week cited Bradbury to indicate that non-viewers were smarter than viewers. We see how dystopian narratives inspire writers; not directly in the sense that predictions are seen to be true, but as a points of reference and a common vocabulary that can be used to distinguish between and add force to arguments. However, with increasing use of television in western democracies, speculations that television would contribute to all-out dystopia ( Chs. 2 and 3) became less prominent. Writers and movements instead used television to explain social ills within existing society.

While different writers and movements ground their resistance in different values, their eclecticism is also striking. The main finding regarding What is at stake? is that works of resistance tended to see television's presence and position in society as bad in many different ways. The books and testimonies discussed here are not academic accounts that easily can be placed within a specific theory or position in media studies - such as moral panic or technological determinism - rather they can be read at sense-making efforts reflecting broadly on negative experiences and disappointments (see Sundet 2012). Studies of people who live without television point to a similar diversity. For example, Krcmar's study (2009) shows that people give up television for many different, and often overlapping, reasons; they might be dissatisfied with content, the medium or the industry, and resistance appeals to a diverse mix with different political and religious beliefs. Whereas Krcmar finds no clear pattern in terms of religious or political affiliations, her comparison between viewers and non-viewers point to a higher level of intensity and lower level of pragmatism among non-viewers. The TV-free had noticeably strong opinions, as Krcmar states: "This is a zealous lot" (42). 
Protesters against early mass media often campaigned for tighter regulation, and for Whitehouse and others resisting television on moral grounds, this was the right course. For those who saw television to be irredeemable, it was more difficult. Collective action against television was inspired by the writings of Postman, Mander and others, but most importantly by the practical approach of Winn who advocated bottom-up television boycotts. The dominant professions in resistance activities were educational and medical, followed by religious, government/community and sports/outdoors. The strength of the endorsers in the US illustrates the ambivalence and scepticism that many professionals felt towards television; television was widely experienced as invasive, threatening authority and autonomy in fields such as politics, science and education (see also Bourdieu 1998). By endorsing turnoff, organizations and professions could act on their scepticism, and, at the same time, promote their aims and goals to a wider public.

The campaigns shows great flexibility and reflexivity; activists are determined not to come across as moralists or luddites, but as intelligent fun-lovers with better things to do than staring at a screen. Although activities such as TV-turnoff week were not immediately effective, abstaining from television could serve a marker of identity. "We do not watch television and in many ways, that is who we are. I think this is a very big thing that defines us," says one of the informants in Krcmar's study $(2009,43)$. Those who had given up television felt that they "are not giving up anything at all. They are merely living without television to improve their lives" (43). Yet, the study shows, those who did not have television often felt labelled as Luddites or cultural reactionaries. One respondent, who voiced his resistance in Christian terms, said that his peers "think we're in a cult" (58). Another said that the assumption was that non-viewers should "drive a horse and buggy or dress all in black" (59).

One aim of the book is to discuss how resistance is sustained and how arguments and values transcend national, historical and media boundaries. An explanation beginning to emerge is the flexible ideology and adaptable forms of action. Television resistance, as discussed in this chapter, appealed to different segments and different organizational concerns, and could be tailored to fit different national debates. I have shown how resistance travelled, how messages were adjusted, and how turnoffs could be utilized to aid different causes in societies with widely different television systems. 
The analysis in this chapter stops in the early 2000s, an era of debate on The End of Television? (Katz and Scannell 2009). Anti-television activism did not undermine television, but is an indication of how the medium was contested. The dislike of television became even more visible at the onset of the digital age.

Open Access This chapter is licensed under the terms of the Creative Commons Attribution 4.0 International License (http://creativecommons.org/licenses/ by $/ 4.0 /$ ), which permits use, sharing, adaptation, distribution and reproduction in any medium or format, as long as you give appropriate credit to the original author(s) and the source, provide a link to the Creative Commons license and indicate if changes were made.

The images or other third party material in this chapter are included in the book's Creative Commons license, unless indicated otherwise in a credit line to the material. If material is not included in the book's Creative Commons license and your intended use is not permitted by statutory regulation or exceeds the permitted use, you will need to obtain permission directly from the copyright holder.

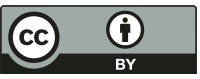

